\title{
Editor's Message: Submarine groundwater discharge studies and the absence of hydrogeologists
}

\author{
Gholam A. Kazemi
}

The objective of this editor's message is to recognize the current efforts, and highlight the need for the wider involvement, of hydrogeologists in a special field of groundwater studies, namely "submarine groundwater discharge". It is also intended to briefly report on the participation of the author in one such study. The term submarine groundwater discharge (SGD), or formerly SGWD, appeared in the literature during the early 1970 s (e.g. Zektser et al. 1973) or even earlier (e.g. Manheim 1967; Glover 1964). However, universal adoption of this expression was not very quick. Bokuniewicz (1980), for instance, used phrases like "submarine outflow of groundwater" or "groundwater flow across the sea floor" to describe the same phenomenon. Long after those early publications, a couple of articles in the high prestige journal Nature (Moore 1996; Younger 1996) and the improvement in analytical facilities gave this subject a boost and, from the mid-1990s onwards, drew the attention of scientists. It was then that the floodgate of related publications opened. Modern equipment capable of quickly and reliably measuring tracers, especially ${ }^{222} \mathrm{Rn}$ and ${ }^{226} \mathrm{Ra}$ (e.g. RAD7), as well as isotopes of seawater dissolved gases such as $\mathrm{CH}_{4}$, and the development of a new generation of seepage meters, all motivated researchers to concentrate again on this subject. Up until a few years ago, quantitative estimation of SGD was difficult/ impossible to achieve and the consequences of SGD on

Received: 4 October 2007 / Accepted: 15 November 2007 Published online: 4 January 2008

(C) Springer-Verlag 2007

\section{G. A. Kazemi (}

Faculty of Earth Sciences,

Shahrood University of Technology,

Shahrood, Iran

e-mail: g_a kazemi@hotmail.com

Tel.: +98-273-3336007

Fax: $+98-273-3334419$

Present Address:

G. A. Kazemi

Division of Earth and Planetary System Science,

Graduate School of Science,

Hokkaido University,

N10 W8, Kita-ku, Sapporo, 060-0810, Japan marine coastal processes were unknown. Since 2000, a number of sites across the globe have been chosen for detailed study of SGD phenomenon including sites in Australia, Brazil, Italy, Mauritius and the USA (Burnett et al. 2006). These studies have employed a range of techniques including seepage meters, tracers, onshore and offshore CTD (conductivity, temperature, depth) profiling and hydrogeological modeling approaches. New methodologies such as LandSat satellite imagery are now being tested.

Annually, about $2,400 \mathrm{~km}^{3}$ of freshwater discharges into the world's seas and oceans in the form of SGD, which is defined as any type of flow of water upwards across the sea floor, from the ocean bottom into the overlying water (SCOR-LOICZ 2004). This amounts to only $6 \%$ of the annual river input into oceans. However, due to its higher dissolved solid content, SGD has considerable impact on the quality and the ecosystem of the receiving waters, as rightly recognized by Johannes (1980).

Generally speaking, marine and oceanography texts or even textbooks of any field do not include a section on SGD (see for example Chester 2003). However, very recently a few books have dealt with this subject, though mostly in a peripheral way. These include Zektser et al. (2007); Judd and Hovland (2007); Davis and Elderfield (2004); Taniguchi et al. (2003), and very marginally Vacher and Quinn (1997). With the exception of the first two, the rest are edited books comprised of a variety of articles by different authors. Considering that the book by Judd and Hovland (2007) only briefly touches the topic, Zektser et al. (2007) is left as the only book entirely dedicated to this matter.

In the world of journals, articles related to SGD have appeared commonly in Limnology and Oceanography, Biogeochemistry, Continental Shelf Research, Estuarine, Coastal and Shelf Science, Earth and Planetary Sciences and to a lesser extent in Geophysical Research Letters, Water Resources Research, Journal of Hydrology, etc. Also, the December 2004 special issue of Ground Water was allocated to SGD, though there have only been a couple of other short articles recently published in that journal (Taniguchi et al. 2005, 2007). In contrast, there are no articles in Hydrogeology Journal that specifically document work on SGD and its characteristics, although there are a few reports that document submarine springs. 
The equivalent of SGD in the hydrogeological literature is perhaps what has been termed "marine hydrogeology". An essay in the Future of Hydrogeology theme issue (Fisher 2005) has narrowly touched this field though not specifically mentioning SGD. Another essay in the same issue is partially related to this subject (Post 2005). These are just not enough, though some hydrogeologists published high-value SGD papers in Nature recently (e.g. Michael et al. 2005). However, one may argue that hydrogeologists have written on this subject, but have not used the term SGD specifically (e.g. Benduhn and Renard 2004). The response to that would be that SGD is a well-established term now, and hydrogeologists should recognize and adapt to it. To further support the point, another example is provided here. A recent comprehensive article (Burnett et al. 2006) reviews the topic of SGD at length and in detail and summarizes the findings of various research projects across the globe. Coauthors of this article, 22 in number, are from a variety of disciplines, mainly from oceanography and marine departments (nine coauthors), with only two coauthors from geological departments. This mixture, which is a good representation of the involvement of professionals with different backgrounds with SGD studies, shows that hydrogeologists are not particularly well represented in this field of groundwater science. Another review article (Gallardo and Marui 2006), which demonstrates the participation of hydrogeologists, has been published in Geo-Marine Letters. SGD comprises three words, two of which (groundwater and discharge) are the main domains of hydrogeologists. Therefore, while appreciating the undertaken research work, no doubt is left that the participation of hydrogeologists in SGD studies has been less than what it should have been. Having said that, it should be added that there are at least two reasons why hydrogeologists are generally absent from this field:

1. Hydrogeological research projects are commonly driven by practical problems (indeed, Hydrogeology Journal used to be called Applied Hydrogeology). In coastal areas, a typical issue is freshwater salinization due to seawater intrusion and, in this respect, hydrogeologists often treat offshore aquifers as a source of salt rather than a sink of freshwater.

2. Measurement of SGD requires seaborne equipment that oceanographers and marine scientists are more familiar with. This obstacle, however, is gradually vanishing because of the ease of operation of sophisticated modern equipment.

Similar to articles and books, a handful of $\mathrm{PhD}$ theses have dealt with this subject. These include: Akawwi 2006; Loveless 2006; Prieto 2005; Michael 2005; Schwartz 2002; Corbett 1999; Young 1996; Robinson 1996 and Millham 1993. Again, these dissertations have been mainly carried out at departments other than Geology or Earth Sciences, though hydrogeologists supervised some.
Akawwi (2006), for example, which quantifies SGD into the Dead Sea, Jordan, was supervised by Martin Sauter and Elias Salameh, two well-known hydrogeologists.

Professional organizations and scientific bodies involved with SGD research projects include Intergovernmental Oceanographic Commission (IOC), Scientific Committee on Oceanic Research (SCOR), Land-Ocean Interactions in the Coastal Zone (LOICZ) and International Association of Physical Sciences of Oceans (IAPSO). Again, here, one could easily see that these bodies, in general, have an ocean-marine root with minimal connection with land hydrology or hydrogeology. As a milestone, the International Atomic Energy Association (IAEA) and UNESCO initiated a 5-year plan in 2000 to study the importance of SGDs and the methodologies used to study SGDs in the management of the coastal zone. This comprehensive research project was carried out by: the Isotope Hydrology Section of IAEA in Vienna, Austria; the Marine Environmental Laboratory in Monaco; the Intergovernmental Oceanographic Commission (IOC), and the International Hydrological Program (IHP), along with nine laboratories in eight countries (Burnett et al. 2006). A couple of commissions by the International Association of Hydrogeologists (IAH), e.g. commissions on groundwater-dependent ecosystem and aquifer dynamics and coastal zone management, relate to SGD, but have not yet focused on this subject.

The author of this editor's message, a hydrogeologist and a member of IAH, is currently a guest researcher at Hokkaido University, Japan to initiate a research program in order to quantify the SGD into the Caspian Sea in Asia from its southern Iranian margins. Concentration and ${ }^{13} \mathrm{C}$ isotope content of methane in the Caspian Sea waters is the main approach that will be adopted. A substantial component of this large project is the continuous collaboration with the Japanese scientists who are front runners in this field. This research project will try to estimate the quantity of SGD into the Caspian Sea using available technology and expertise at the University of Hokkaido, which is one of only a handful of institutions in the world with the capacity to measure ${ }^{13} \mathrm{C}$ content of methane in water samples. Water samples from the Caspian Sea and adjoining aquifers will be analyzed for this purpose. As yet, there has been no published work, whether national or international, on this region. Iranian shorelines of the Caspian Sea are $750 \mathrm{~km}$ in length, just over $10 \%$ of the total shoreline. However, higher hydraulic gradients, as well as higher rainfall in the southern Caspian Sea area, result in a proportionally greater share of the SGD for this region. Based on an estimate by Zektser et al. (2007), about 30\% of Caspian Sea SGD is from the Iranian side.

The intention of this editor's message is to alert fellow hydrogeologists to the need for further participation in such studies. Hydrogeologists can improve SGD studies by quantitative analysis of groundwater flow dynamics in coastal aquifers. This complements the current, mainly tracers-orientated studies adopted by marine scientists and 
oceanographers, which focus on the SGD at surface, i.e. after entering surface waters. The involvement of hydrogeologists can lead to a more complete picture of subsurface flow conditions and the effect of this flow field on coastal processes. One very good recent example is the work by Thompson et al. (2007), which shows how isotopic tracers alone may be misleading. In addition, hydrogeologists need to be aware of SGD because the unawareness of SGD and fresh groundwater in the offshore realm can lead to misunderstanding of the hydrogeology of coastal aquifers. For example, the salinization of a coastal well field is (in general) instantly attributed to seawater encroachment. However, if relatively fresh groundwater is present below the seafloor, this explanation is incorrect and a different cause is to be held responsible for the salinization process. Therefore, even if hydrogeologists are not directly involved in quantification of SGD itself, they need to be more aware of it than is presently the case.

Based on the above explanation, there is a need to include SGD in the curriculum of groundwater hydrology and hydrogeology subjects of the Geology and Earth Science departments of universities. Topics like definition and description of SGD, sampling and measurement techniques, the impact of SGD on the receiving waters and the coastal processes, factors controlling SGD quantity, the impact of seawater level fluctuations on the quantity of SGD, SGD as a water resources management issue and case studies worldwide should be taught as part of this subject. Seawater intrusion, the other side of the SGD coin, has been a core subject of hydrogeologygroundwater textbooks. SGD, however, has not found its rightful place in these types of texts and there is a justified need to include a thorough discussion in newly published books, as well as in subsequent editions of the present hydrogeology textbooks.

Acknowledgements One should not write an editorial message about SGD that does not mention the name of William Burnett from the Oceanography Department of the Florida State University, USA. Prof. Burnett has written extensively on this subject for the past 12 years and has been the driving force behind these kinds of research projects. He has participated in almost all of the SGD case studies worldwide and continues to do so. Makoto Taniguchi from Research Institute for Humanity and Nature (RIHN), Japan, has also been a key researcher in this field and has invented the Taniguchitype seepage meter. Prof. Taniguchi is the most active and highly published member of IAH in the field of SGD. I should also acknowledge with thanks the Matsumae International Foundation (MIF), Tokyo, Japan, for the award of the MIF fellowship. Further, special thanks go to Prof. U. Tsunogai from the Graduate School of Science, Hokkaido University for his hospitality and for providing access to the analytical facilities at his geochemistry laboratory. Lastly, this message has benefited from the comments and editing of Sue Duncan, Maria-Theresia Schafmeister, Philippe Renard, Charles Harvey and especially Vincent Post and I am grateful to all.

\section{References}

Akawwi E (2006) Locating zones and quantifying the submarine groundwater discharge into the eastern shores of the Dead Sea-
Jordan. PhD Thesis, Georg-August University of Goettingen, Germany

Benduhn F, Renard P (2004) A dynamic model of the Aral Sea water and salt balance. J Mar Syst 47:35-50

Bokuniewicz H (1980) Groundwater seepage into Great South Bay, New York. Estuar Coast Mar Sci 10:437-444

Burnett WC, Aggarwal PK, Aureli A, Bokuniewicz H, Cable JE, Charette MA, Kontar E, Krupa S, Kulkarni KM, Loveless A, Moore WS, Oberdorfer JA, Oliveira J, Ozyurt N, Povinec P, Privitera AMG, Rajar R, Ramessur RT, Scholten J, Stieglitz T, Taniguchi M, Turner JV (2006) Quantifying submarine groundwater discharge in the coastal zone via multiple methods. Sci Total Environ 367:498-543

Chester R (2003) Marine geochemistry. 2nd edn., Wiley-Blackwell, Boston, MA

Corbett DR (1999) Tracing groundwater flow into surface waters by application of natural and artificial tracers. PhD Thesis, Florida State University, USA

Davis EE, Elderfield H (2004) Hydrogeology of the oceanic lithosphere. Cambridge University Press, Cambridge, UK

Fisher AT (2005) Marine hydrogeology: recent accomplishments and future opportunities. Hydrogeol J 13:69-97

Gallardo AH, Marui A (2006) Submarine groundwater discharge: an outlook of recent advances and current knowledge. Geo-Mar Lett 26:102-113

Glover RE (1964) The pattern of freshwater flowing in a coastal aquifer in seawater in coastal aquifers. US Geol Surv Water Supply Pap 1613-C, pp 32-35

Johannes RE (1980) The ecological significance of the submarine discharge of groundwater. Mar Ecol Prog Ser 3:365-373

Judd A, Hovland M (2007) Seabed fluid flow: the impact on geology, biology, the marine environment. Cambridge University Press, Cambridge, UK

Loveless AM (2006) Biogeochemical, spatial and temporal dynamics of submarine groundwater discharge in an oligotrophic semienclosed coastal embayment. PhD Thesis, University of Western Australia, Australia

Manheim FT (1967) Evidence for submarine discharge of water on the Atlantic continental slope of the southern United States, and suggestions for future research. New York Acad Sci Trans Ser II 29:839-853

Michael HA, Mulligan AE, Harvey CF (2005) Seasonal oscillations in water exchange between aquifers and the coastal ocean. Nature 436:1145-1148

Michael HA (2005) Seasonal dynamics in coastal aquifers: investigation of submarine groundwater discharge through field measurements and numerical models. PhD Thesis, Massachusetts Institute of Technology, USA

Millham NP (1993) Groundwater flow to a shallow coastal embayment: Little Pond, Cape Cod, Massachusetts. PhD Thesis, Boston University, USA

Moore WS (1996) Large groundwater inputs to coastal waters revealed by ${ }^{226} \mathrm{Ra}$ enrichments. Nature 380:612-614

Post VEA (2005) Fresh and saline groundwater interaction in coastal aquifers: Is our technology ready for the problems ahead? Hydrogeol J 13:120-123

Prieto C (2005) Groundwater-seawater interactions: Seawater intrusion, submarine groundwater discharge and temporal variability and randomness effects. PhD Thesis, KTH-Royal Institute of Technology, Sweden

Robinson MA (1996) A finite element model of submarine groundwater discharge to tidal estuarine waters. PhD Thesis, Virginia Polytechnic Institute, USA

Schwartz MC (2002) Submarine groundwater discharge in the Delaware Estuary: an assessment from excess radon-222. PhD Thesis, University of Delaware, USA

Scientific Committee on Oceanic Research-Land-Ocean Interactions in the Coastal Zone (SCOR-LOICZ) (2004) Submarine groundwater discharge: management implications, measurements and effects. IHP-VI series on groundwater No. 5, IOC manuals and guides No. 44. UNESCO, Paris 
Taniguchi M, Wang K, Gamo T (2003) Land and marine hydrogeology. Elsevier, Amsterdam

Taniguchi M, Ishitobi T, Saeki K (2005) Evaluation of time-space distributions of submarine groundwater discharge. Ground Water 43:336-342

Taniguchi M, Ishitobi T, Burnett WC, Wattayakorn G (2007) Evaluating ground water-sea water interactions via resistivity and seepage meters. Ground Water 45(6):729-735.

Thompson C, Smith L, Maji R (2007) Hydrogeological modeling of submarine groundwater discharge on the continental shelf of Louisiana. J Geophys Res 112, C03014. DOI 10.1029/ 2006JC003557
Vacher L, Quinn T (1997) Geology and hydrogeology of carbonate islands, vol 54 (Developments in sedimentology). Elsevier, Amsterdam

Young JE (1996) Tracing groundwater flow into the northeastern Gulf of Mexico using naturally occurring Radon-222. PhD Thesis, Florida State University, USA

Younger PL (1996) Submarine groundwater discharge. Nature 382:121-122

Zektser IS, Ivanov VA, Meskheteli AV (1973) The problem of direct groundwater discharge to the Seas. J Hydrol 20:1-36

Zektser IS, Everett LG, Dzhamalov RG (2007) Submarine groundwater. CRC, Boca Raton, FL 